DAKWATUNA

Jurnal Dakwah dan Komunikasi Islam

Volume 6, Nomor 2, Agustus 2020

p-ISSN: 2443-0617

e-ISSN: $2686-1100$

\title{
Implementasi Komunikasi Organisasi dalam Kegiatan Dakwah untuk Memperbaiki Diri Narapidana di Lembaga Pemasyarakatan Kelas IIB Lumajang
}

\author{
Moh. Muafi Bin Thohir \\ Institut Agama Islam Syarifuddin Lumajang, Indonesia \\ Email: muafilumajang@gmail.com \\ Syamsul Hadi HM \\ Institut Agama Islam Syarifuddin Lumajang, Indonesia \\ Email: syamsulhadihm@yahoo.co.id
}

\begin{abstract}
Da'wah has been going on for a long time among inmates in prison. Preaching took place at that place for a long time, namely during the Dutch government around 1917. After Indonesia's independence, the da'wah among prisoners was increasingly enhanced until now. The correctional system can be briefly said as a process of fostering prisoners based on a noble soul, and therefore also regards Prisoners as fellow creatures of God, individuals and members of the community. And in fostering prisoners, their mental life (including their religious life), physical and social life must be developed. With the correctional system, which means a renewal of the system in order to foster a complete human being, it is very necessary to have the right da'wah method, in accordance with and in tune with the correctional system. Penitentiary (Lembaga Pemasyarakatan) is a place to carry out guidance for prisoners and correctional students. Organizational communication is needed to carry out maximum coaching activities to achieve a goal and service that is satisfying for prisoners, as well as being a safe, orderly, free of extortion, drug and cell phone institution. Dai who was given the mandate at Lumajang Class IIB Correctional Institution had fulfilled the criteria of both scientific potential and personality potential so that the method used was in accordance with the madami faced by the prisoners who mostly inhabited the Class IIB Correctional Institution in Lumajang were drug cases. The average drug case is adolescence. The clerics always emphasize lectures on efforts to improve themselves both in the field of skills and personal because it is feared that after leaving the Lumajang Class II Correctional Institution unable to do something that can fulfill life. The challenge faced is the lack of seriousness of prisoners participating in the da'wah activities carried out by the Lumajang Class II Correctional Institution. This is due to prisoners having a level of memory that is tired because of drug addiction.
\end{abstract}

Keywords: Da'wah, Organizational Communication, Penitentiary

\begin{abstract}
Abstrak
Dakwah agama Islam telah lama berlangsung di kalangan narapidana (Napi) di Lembaga Pemasyarakatan. Berlangsungnya dakwah ditempat tersebut sudah sejak lama yaitu pada zaman pemerintah Belanda sekitar tahun 1917. Setelah Indonesia merdeka maka dakwah di kalangan narapidana makin ditingkatkan
\end{abstract}


sampai sekarang. Sistem pemasyarakatan dengan singkat dapat dikatakan sebagai suatu proses pembinaan narapidana berdasarkan jiwa luhur, dan oleh karena itu pula memandang Narapidana sebagai sesama makhluk tuhan, individu dan anggota masyarakat. Dan dalam pembinaan terhadap Napi perlu dikembangkan kehidupan kejiwaannya (termasuk kehidupan agamanya), jasmaniahnya serta kehidupan kemasyarakatan. Dengan adanya sistem pemasyarakatan, yang berarti suatu pembaruan sistem dalam rangka membina manusia seutuhnya, maka sangat diperlukan adanya metode dakwah yang tepat, sesuai dan seirama dengan sistem pemasyarakatan. Lembaga Pemasyarakatan (Lapas) merupakan tempat untuk melaksanakan pembinaan bagi narapidana dan anak didik Pemasyarakatan. Komunikasi organisasi sangat dibutuhkan untuk terlaksananya kegiatan pembinaan yang maksimal untuk mencapai suatu tujuan dan pelayanan yang memuaskan bagi warga binaan pemasyarakatan, serta menjadi Lembaga yang aman, tertib, bebas dari pungli, narkoba dan HP. Dai yang diberi amanah di Lembaga Pemasyarakatan Klas IIB Lumajang sudah memenuhi kriteria baik kompotensi keilmuwan maupun kompotensi kepribadian sehingga metode yang digunakan sudah sesuai dengan mad'u yang dihadapi narapida yang paling banyak mendiami Lembaga Pemasyarakatan Klas IIB Lumajang adalah kasus narkoba. Rata-rata yang kasus narkoba adalah usia remaja. Para ustad selalu menekankan ceramah pada usaha untuk memperbaiki diri baik dalam bidang keterampilan maupun pribadatan karena dihawatirkan nanti setelah keluar dari Lembaga Pemasyarakatan Klas IIB Lumajang tak mampu melakukan sesuatu yang bisa memenuhi hidup. Tantangan yang dihadapi adalah ketidakseriusan narapidana mengikuti kegiatan dakwah yang dilakukan Lembaga Pemasyarakatan Klas IIB Lumajang. Hal ini disebabkan narapidana memiliki tingkat memori yang sudah lelah karena terbius narkoba.

Kata Kunci: Dakwah, Komunikasi Organisasi, Lembaga Pemasyarakatan

\section{PENDAHULUAN}

Lembaga Pemasyarakatan (Lapas) adalah tempat untuk melaksanakan pembinaan narapidana dan anak didik pemasyarakatan, hal ini sesuai dengan UU Nomor 12 Tahun 1995 tentang pemasyarakatan. Lembaga Pemasyarakatan merupakan tempat yang dibuat oleh negara di masing- masing kota, sebagai salah satu institusi penegak hukum yang diharapkan mampu memberikan titik jera kepada narapidana. Namun Lapas juga bukan tempat untuk menyiksa narapidana atau anak didik pemasyarakatan. Lapas berfungsi sebagai tempat untuk meningkatkan kualitas narapidana, tempat rehabilitasi narapidana, dan 
melaksanakan pembinaan agar narapidana menyadari kesalahan, memperbaiki diri, dan tidak mengulangi tindak pidana. Sehingga dapat diterima kembali oleh lingkungan masyarakat, dapat berperan aktif di kehidupan sosial serta dapat hidup secara wajar sebagaimana warga yang baik dan bertanggung jawab. ${ }^{1}$

Lapas Klas IIB Lumajang sebagai suatu organisasi yang berada di bawah naungan pemerintah memiliki tugas yang sangat besar untuk negara. Pembinaan terhadap narapidana merupakan suatu kegiatan yang harus terencana dan terkonsep dengan baik. Pelaksanaan pembinaan/kegiatan dakwah yang berada di Lapas merupakan salah satu bagian dari implementasi komunikasi organisasi. Komunikasi organisasi merupakan faktor fundemantal dalam mengelola sebuah komunitas, termasuk di dalamnya komunitas atau kelompok orang yang berstatus narapidana dalam sebuah Lapas. Sebagai contoh, dalam sebuah pemerintahan yang di dalamnya ada unsur hirearkis, komunikasi organisasi yang sesuai perkembangan zaman akan mengoptimalkan kinerja para petugas untuk menjalankan tanggung jawabnya di lapangan². Sudah banyak pemerintah yang berinovasi untuk menjalankan pelayanan publik dan kinerja aparatnya, baik di bidang ekonomi ${ }^{3}$, industri kreatif $^{4}$, dan lain sebagainya. Bahkan, di bidang pendidikan anak berkebutuhan khusus $^{5}$. Artinya, inovasi di segela lini adalah sebuah keniscayaan.

Selain itu Lapas juga mengatur segala keamanan, memenuhi segala kebutuhan narapidana, dan membuat peraturan yang harus ditaati oleh

\footnotetext{
${ }^{1}$ A. Royad Shaleh, Manajemen Dakwah Islam, ( Jakarta: Al-Ikhlas, 2010), hlm. 24

${ }^{2}$ Rio Febriannur Rachman. (2019). Optimalisasi Teknologi Komunikasi Informasi Command Center Bagi Efektifitas Tenaga Kesejahteraan Sosial Kecamatan. Dakwatuna: Jurnal Dakwah dan Komunikasi Islam, 5(2), 170-180.

${ }^{3}$ Rio Febriannur Rachman. (2019). Optimalisasi Media Digital Berbasis Kemaslahatan Umat dalam Program Pahlawan Ekonomi Surabaya. IQTISHODUNA: Jurnal Ekonomi Islam, 8, 273-292.

${ }^{4}$ Rio Febriannur Rachman. (2019). Pengembangan Industri Kreatif Berbasis Media Digital di Surabaya dalam Perspektif Islam. KOMUNITAS, 10(2), 157-176.

${ }^{5}$ Rio Febriannur Rachman. (2020). Kebijakan Pendidikan Anak Berkebutuhan Khusus Di Surabaya Dalam Perspektif Islam. Bidayatuna: Jurnal Pendidikan Guru Mandrasah Ibtidaiyah, 3(01), 125-143.
} 
seluruh bagian Lapas (Kepala Lapas, pegawai, staf, narapidana, tahanan, pengunjung, bahkan pembina dari luar, polisi, dan lain sebagainya) merupakan suatu usaha yang tiada henti dilakukan Lapas Lumajang untuk mengantisipasi ancaman yang akan menghambat organisasi, berbagai usaha ini tidak lain untuk kebaikan narapidana dan proses untuk pencapaian tujuan organisasi.

Lembaga Pemasyarakatan Klas IIB Lumajang pada hari Selasa, 27 Desember tahun 2019, tercatat 435 penghuni Lapas dengan berbagai macam tindak pidana yang telah dilakukan. Padahal kapasitas hunian hanya 249 orang. Melihat banyaknya narapidana dan keterbatasan tempat hunian, tujuan yang ingin dicapai oleh Lapas Lumajang adalah agar narapidana yang dinyatakan bebas dan telah melaksanakan proses hukuman sesuai dengan keputusan pengadilan, tidak mengulangi kesalahan atau tindak pidana kembali. Lapas juga berharap agar para narapidana yang masih menjalani hukuman untuk terus memperbaiki diri. Proses dalam pencapaian tujuan inilah membutuhkan peran dari implementasi komunikasi organisasi, bahwa dalam setiap pelaksanaan kegiatan di Lapas tidak lepas dari organisasi, untuk itu komunikasi organisasi sangat dibutuhkan dalam menyampaikan tugas-tugas disetiap kegiatan yang berada di Lapas Klas IIB Lumajang, terutama untuk kegiatan pembinaan agama/dakwah. Sebab dalam kegiatan dakwah inilah peran Lapas sangat besar untuk memperbaiki diri narapidana. Lembaga Pemasyarakatan Klas IIB Lumajang, melakukan berbagai cara untuk memperbaiki diri narapidana, dengan memberikan ilmu pengetahuan dan agama kepada narapidana. Sesuai dengan QS. Ali Imran ayat 104, Allah SWT berfiman: Yang artinya: "Dan hendaklah ada di antara kamu segolongan umat yang menyeru kepada kebajikan, menyuruh kepada yang ma'ruf dan mencegah dari yang munkar, merekalah orang-orang yang beruntung."6

Lembaga Pemasyarakatan Klas IIB Lumajang, narapidananya selalu

\footnotetext{
${ }^{6}$ M. Abdul Azizi, Ilmu Dakwah, (Jakarta: Prenada Media Group, 2009), 146.
} 
diarahkan untuk mengerjakan kebaikan seperti halnya kegiatan pembinaan keagamaan, narapidana diwajibkan untuk belajar fiqih, membaca dan menulis Al-Qur'an, serta siraman rohani, dan mewajibkan mengerjakan sholat wajib dan sunnah berjama'ah. Kegiatan umum, seperti belajar baca tulis bagi narapidana yang belum bisa baca tulis, belajar kesenian dengan menggunakan bahan-bahan bekas, sehingga menghadirkan kreatifitas diri narapidana, kegiatan produksi yaitu pembuatan paving blok, kegiatan pertukangan, perikanan, dan perkebunan agar bisa diterapkan ketika keluar dari Lapas.

Komunikasi sangat dibutuhkan dalam kehidupan ini, baik komunikasi verbal atau non verbal. Begitu juga dalam organisasi, sebuah organisasi tidak akan bisa berlangsung tanpa adanya komunikasi. Komunikasi organisasi adalah proses interaksi antara komunkator dan komunikan untuk menciptakan dan menafsiran pesan di antara unit-unit komunikasi yang merupakan bagian dari suatu organisasi tertentu, dan berfungsi dalam suatu lingkungan yang sama, agar bisa mengatasi masalah-masalah yang terjadi secara terus-menerus dan berubah-ubah. Komunikasi organisasi dipandang sebagai suatu proses penciptaan makna atas interaksi yang terjadi dalam suatu organisasi. Penciptaan yang dibentuk dalam suatu komunikasi organisasi memiliki tujuan yang sangat penting dalam organisasinya. Untuk itu komunikasi menjadi tonggak utama keberhasilan suatu organisasi dalam mengkondisikan anggotaanggotanya dan dalam menerapkan berbagai tugas yang diberikan.

Komunikasi organisasi sangat dibutuhkan untuk menyampaikan pesan dalam pelaksanaan tugas, baik oleh atasan ke bawahan atau sebaliknya. Sebab dalam suatu organisasi harus memiliki tujuan yang sama dan saling bekerjasama. Seperti halnya implementasi komunikasi organisasi di Lembaga Pemasyarakatan sangat dibutuhkan untuk mengamankan, mengatur, mengagendakan segala kegiatan pembinaan narapidana, serta memenuhi hak-

\footnotetext{
${ }^{7}$ R. Wayne Pace dan Don F. Faules, Komunikasi Organisasi Strategi Meningkatkan Kinerja Perusahaan (Bandung: PT Remaja Rosdakarya, 2001), 33.
} 
hak narapidana. Mulai dari melakukan ibadah sesuai dengan agama atau kepercayaannya, mendapatkan perawatan rohani dan jasmani, mendapatkan pendidikan dan pengajaran, mendapatkan pelayanan kesehatan dan makanan yang layak, menyampaikan keluhan, mendapatkan bahan bacaan, mendapatkan upah atas pekerjaan yang dilakukan, menerima kunjungan keluarga, penasihat hukum, atau orang tertentu lainnya, mendapatkan pengurangan masa pidana (remis), mendapatkan kesempatan cuti mengunjungi keluarga, mendapatkan pembebasan bersyarat, mendapatkan cuti menjelang bebas, dan mendapatkan hak-hak lain sesuai dengan UU Nomor 12 Tahun 1995.

Lapas Klas IIB Lumajang dalam mencapai tujuannya untuk memperbaiki diri narapidana, maka bekerjasama dengan berbagai pihak untuk melakukan pembinaan yang tepat kepada narapidana. Seperti halnya bekerjasama dengan kampus IAIS Lumajang, Kementerian Agama Lumajang, Pondok Pesantren Mamba'ul Hikam 02, dan Yayasan Al- Yasini. Hal ini merupakan bentuk usaha yang terus dikembangkan oleh Lapas Lumajang dalam membina warga binaan pemasyarakatan, dengan adanya berbagai macam kegiatan pembinaan itu, terdapat banyak narapidana yang sudah menyadari kesalahannya, serta mampu memperbaiki diri menjadi insan yang lebih baik.

Melihat keadaan seperti ini, sungguh Lapas mempunyai pengaruh yang sangat besar untuk memperbaiki diri narapidana. Namun, di sisi lain pada bulan Januari tahun 2019 tercatat 65 orang narapidanan residivis, yang berasal dari dalam dan luar kota dengan beberapa macam tindak pidana, di antaranya mencuri, perampasan, merampok, jambret, penganiayaan. Adanya narapidana residivis menjadi salah satu bukti bahwa Lapas tidak bisa mewujudkan 100\% keberhasilan dalam memperbaiki diri narapidana. Hal ini menjadi suatu problem yang harus diatasi oleh Lapas Klas IIB Lumajang, belum lagi mengingat ada banyak pemindahan narapidana dari Lapas lain ke Lapas Lumajang. Untuk itu Lapas Klas IIB Lumajang harus menghadapi dan 
mengatasi segala ancaman/hambatan yang ada, dan bahwa kejahatan yang terorganisasi akan mampu mengalahkan kebaikan yang tidak terorganisasi.

\section{PEMBAHASAN}

Menurut Agustino implementasi adalah kegiatan untuk mendistribusikan keluaran kebijakan yang dilakukan oleh para implementor kepada sasaran sebagai upaya untuk mewujudkan kebijakan. Dalam pendekatan teori model implementasi menurut George C. Edward III mengenalkan empat variabel yang mempengaruhi keberhasilan implementasi suatu kebijakan yaitu komunikasi, sumberdaya, disposisi dan struktur birokrasi. Implementasi adalah suatu tindakan atau pelaksanaan dari sebuah rencana yang sudah disusun secara matang dan terperinci. Implementasi biasanya dilakukan setelah perencanaan sudah dianggap sempurna. Menurut Nurdin Usman, implementasi adalah bermuara pada aktivitas,aksi,tindakan atau adanya mekanisme suatu sistem, implementasi bukan sekedar aktivitas , tapi suatu kegiatan yang terencana dan untuk mencapai tujuan kegiatan. ${ }^{8}$ Guntur Setiawan berpendapat, implementasi adalah perluasan aktivitas yang saling menyesuaikan proses interaksi antara tujuan dan tindakan untuk mencapainya serta memerlukan jaringan pelaksana,birokrasi yang efektif. ${ }^{9}$

Dari pengertian-pengertian diatas memperlihatkan bahwa kata implementasi bermuara pada mekanisme suatu sistem. Berdasarkan pendapat para ahli diatas maka dapat disimpulkan implementasi adalah suatu kegiatan yang terencana, bukan hanya suatu aktifitas dan dilakukan secara sungguhsungguh berdasarkan acuan norma-norma tertentu untuk mencapai tujuan kegiatan. Oleh karena itu, impelementasi tidak berdiri sendiri tetapi dipengaruhi oleh objek berikutnya yaitu kurikulum. Implementasi kurikulum

\footnotetext{
${ }^{8}$ Nurdin Usman, Konteks Implementasi Berbasis Kurikulum,( Jakarta: Grasindo, 2002 ), 70

${ }^{9}$ Guntur Setiawan, Impelemtasi dalam Birokrasi Pembangunan, ( Jakarta: Balai Pustaka, 2004), 39
} 
merupakan proses pelaksanaan ide,program atau aktivitas baru dengan harapan orang lain dapat menerima dan melakukan perubahan terhadap suatu pembelajaran dan memperoleh hasil yang diharapkan.

Komunikasi menurut Everett M. Rogers adalah proses di mana suatu ide dialihkan dari sumber kepada suatu penerima atau lebih, dengan maksud untuk merubah tingkah laku mereka. Mary B. Cassata dan Molefi K. Asante, mengatakan komunikasi adalah transmisi informasi dengan tujuan mempengaruhi khalayak. ${ }^{10}$ Organisasi adalah sebuah wadah yang menampung orang-orang dan objek-objek dalam organisasi yang berusaha mencapai tujuan bersama.

Teori organisasi merupakan teori yang akan membantu melihat proses komunikasi dalam organisasi, dalam hal ini akan membahas dua teori organisasi, yaitu: a. Teori Hubungan Manusia; Manusia sebagai anggota organisasi merupakan inti organisasi sosial. Teori ini menekankan pada pentingnya individu dan hubungan sosial dalam kehidupan organisasi. Teori ini menyarankan strategi peningkatan dan penyempurnaan organisasi dengan meningkatkan kepuasan anggota organisasi dan menciptakan organisasi yang dapat membantu individu mengembangkan potensinya. Teori ini, diperkenalkan oleh Barnard 1938, Mayo 1933, Roethlisherger dan Dichcon 1939. ${ }^{11}$ Dalam studi Hawthorne, menghasilkan 2 kesimpulan yang sering disebut efek Hawthorne, yaitu: 1). Perhatian terhadap orang-orang boleh jadi merubah sikap dan perilaku mereka. 2). Moral dan produktivitas dapat meningkat apabila para pegawai mempunyai kesempatan untuk berinteraksi satu sama lainnya. Kemudian Mayo (1945) menulis suatu ulasan yang

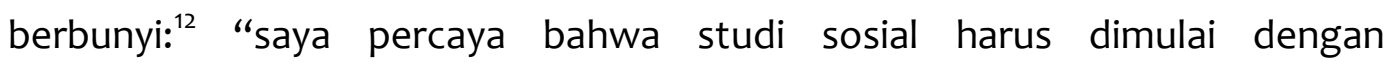

\footnotetext{
${ }^{10}$ Deddy Mulyana, Ilmu Komunikasi Suatu Pengantar (Bandung: PT Remaja Rosdakarya, 2007), 69.

${ }^{11}$ Arini Muhammad, Komunikasi Organisasi (Jakarta: Bumi Aksara, 2011), 40.

${ }^{12}$ R. Wayne Pace dan Don F. Faules, Komunikasi Organisasi Strategi Meningkatkan Kinerja Perusahaan (Bandung: PT Remaja Rosdakarya, 2001), 60.
} 
pengamatan yang teliti mengenai apa yang disebut komunikasi: yakni, kemampuan seorang individu untuk menyatakan perasaan dan gagasannya kepada orang lain, kemampuan kelompok untuk berkomunikasi secara efektif dan intim dengan kelompok lainnya. Itulah, tidak diragukan lagi, kerusakan utama yang dialami peradaban manusia dewasa ini." b.Teori Sistem Sosial; Teori ini memandang organisasi sebagai kaitan bermacam- macam komponen yang saling tergantung satu sama lain dalam mencapai tujuan organisasi. Setiap bagian mempunyai peranan masing-masing dan berhubungan dengan bagian-bagian lain dan karena itu koordinasi penting dalam teori ini. Teori ini diperkenalkan oleh Katz dan Kahn yang menekankan kepada integritas fungsional dan unit-unit sistem dalam menyelesaikan aktivitas organisasi. Ada empat implikasi penting dari teori sistem ini untuk analis organisasi dan komunikasi organisasi. 1). Interdependence atau saling bergantung kepada yang lain, agar organisasi bekerja secara efektif maka semua unit organisasi harus dikoordinasi. 2). Keterbukaan, implikasinya bahwa organisasi harus hatihati terhadap perubahan lingkungan, karena lingkungan dapat menghambat aktivitas organisasi. Analisis yang bersifat sangat kecil dan sangat besar, implikasinya bahwa ada banyak tingkat organisasi dalam suatu organisasi. Untuk memahami organisasi kita harus menginterpretasikan pekerjaan dalam sistem (mikrofis) dan saling berhubungan organisasi dengan lingkungannya (makrofis). Penyesuaian dan pembaruan organisasi, organisasi harus fleksibel dan dapat menerima secara terus-menerus pembaruan untuk menghadapi hambatan perubahan dari lingkungan sistem. ${ }^{13}$

Komunikasi organisasi merupakan perilaku pengorganisasian yang terjadi dan bagaimana mereka yang terlibat dalam proses itu bertransaksi dan memberi makna atas apa yang sedang terjadi. ${ }^{14}$ Goldhaber memberikan

\footnotetext{
${ }^{13}$ Arini Muhammad, Komunikasi Organisasi (Jakarta: Bumi Aksara, 2011), 54.

${ }^{14}$ R. Wayne Pace dan Don F. Faules, Komunikasi Organisasi Strategi Meningkatkan Kinerja Perusahaan (Bandung: PT Remaja Rosdakarya, 2001), 33.
} 
definisi komunikasi organisasi adalah proses menciptakan dan saling menukar pesan dalam satu jaringan hubungan yang saling tergantung satu sama lain untuk mengatasi lingkungan yang tidak pasti atau selalu berubah-ubah. Terdapat tujuh konsep kunci dalam komunikasi organisasi, di antaranya: a. Proses, suatu organisasi akan menciptakan dan menukar informasi secara terus menerus dan tidak ada henti-hentinya. b. Pesan, Thayer mengemukakan empat fungsi khusus dari arus pesan dalam organisasi, yaitu untuk memberi informasi, untuk mengatur, untuk membujuk dan mengintegrasikan. Sedangkan Goldhaber menambahkan pesan inovasi sebagai suatu cara untuk menyesuaikan diri dengan lingkungan yang selalu berubah-ubah. Misalnya rencana baru organisasi, kegiatan baru, program baru atau pengarahan yang dapat membangkitkan pemecahan masalah. ${ }^{15}$ c. Jaringan, merupakan pedoman ke mana seseorang dapat berkomunikasi. Arah jaringan komunikasi dibagi menjadi tiga, yaitu: komunikasi dari atas ke bawah, berkenaan dengan tugas- tugas atau pemeliharaan organisasi. Komunikasi dari bawah ke atas, dirancang untuk menyediakan umpan balik tentang seberapa baik organisasi telah berfungsi. Komunikasi horizontal merupakan aliran komunikasi kepada orang-orang yang memiliki hierarki sama dalam suatu organisasi, ${ }^{16}$ biasanya berhubungan dengan pemecahan masalah koordinasi. d. Keadaan saling tergantung, keadaan saling tergantung satu bagian dengan bagian lainnya, sebab organisasi merupakan suatu sistem yang terbuka. Implikasinya, bila pimpinan membuat suatu keputusan dia harus memperhitungkan implikasi keputusan itu terhadap organisasinya secara menyeluruh. e. Hubungan, Pace dan Boren menggunakan istilah hubungan interpersonal terhadap komunikasi yang terjadi dalam hubungan tatap muka, dengan membedakan empat macam komunikasi yaitu komunikasi dyadic (antara dua orang), komunikasi serial (komunikasi dyadic yang diperluas berupa satu seri ), komunikasi

\footnotetext{
${ }^{15}$ Arini Muhammad, Komunikasi Organisasi (Jakarta: Bumi Aksara, 2011), 70.

${ }^{16}$ Khomsahrial Romli, Komunikasi Organisasi Lengkap (Jakarta: PT Grasindo, 2014), 192.
} 
kelompok kecil (komunikasi antara 3-12 orang), komunikasi audience atau kelompok besar (terdiri 13 orang lebih). f. Lingkungan, semua totalitas secara fisik dan faktor sosial yang diperhitungkan dalam pembuatan keputusan mengenai individu dalam suatu sistem. Dewasa ini, organisasi harus memonitor faktor lingkungan eksternalnya seperti peraturan pemerintah, isu dalam masyarakat, kontroversi politik, perbedaan kultur dan sebagainya. Karena lingkungan berubah-ubah, maka organisasi memerlukan informasi baru. Informasi ini harus dapat mengatasi perubahan dalam lingkungan dengan menciptakan dan pertukaran pesan baik secara internal dalam unitunit yang relevan maupun terhadap kepentingan umum secara eksternal. g. Ketidakpastian, perbedaan informasi yang tersedia dengan informasi yang diharapkan. Untuk mengurangi faktor ketidakpastian ini organisasi harus menentukan dengan tepat berapa banyaknya informasi yang diperlukan untuk mengurangi ketidakpastian tanpa informasi yang berlebihan. ${ }^{17}$

Dalam komunikasi organisasi terdapat tiga format interaksi agar komunikasi bisa berjalan dengan lancar, yaitu: a. Komunikasi Interpersonal adalah proses pertukaran informasi diantara seseorang dengan paling kurang seorang lainnya dan biasanya di antara dua orang yang dapat langsung diketahui balikannya. Komunikasi interpersonal yang efektif akan menjadi salah satu dasar untuk berhasilnya suatu organisasi. Tujuannya untuk mengakrapkan hubungan dengan orang lain dalam organisasi dan untuk merubah sikap dan perilaku orang lain. Komunikasi interpersonal mengenalkan teori interaksi simbolik yang digagas oleh George Herbert Mead pada tahun 1934. Teori interaksi simbolik ini berusaha untuk menggambarkan bagaimana manusia menggunakan bahasa untuk membentuk makna, bagaimana manusia menciptakan serta menampilkan dirinya sendiri, dan bagaimana manusia menggunakan simbol-simbol untuk menciptakan masyarakat dengan cara bekerja sama dengan orang lain. Teori ini kemudian

\footnotetext{
${ }^{17}$ Khomsahrial Romli, Komunikasi Organisasi Lengkap (Jakarta: PT Grasindo, 2014), 194
} 
dikembangkan oleh Herbert Blumer dengan merumuskan 3 buah premis, yaitu: 1). Perilaku manusia dipengaruhi oleh makna yang mereka miliki tentang orang lain dan berbagai kejadian. 2). Interaksi sangat penting bagi perkembangan dan penyampaian pesan. 3). Makna yang dimiliki seseorang tentang berbagai kejadian atau yang lainnya dapat berubah seiring dengan berjalannya waktu. b. Komunikasi Kelompok Kecil menurut Shaw adalah suatu kumpulan individu yang dapat mempengaruhi satu sama lain, berinteraksi untuk beberapa tujuan, mengambil peran, terikat satu sama lain dan berkomunikasi tatap muka. Tujuannya untuk mengatasi suatu permasalahan yang terjadi dan pembuatan keputusan dalam suatu organisasi. c. Komunikasi Publik adalah pertukaran pesan dengan sejumlah orang yang berada dalam organisasi atau yang di luar organisasi, secara tatap muka atau melalui media. Tujuannya untuk memberikan informasi kepada sejumlah besar orang mengenai organisasi dan untuk menjalin hubungan antara organisasi dengan masyarakat di luar organisasi. ${ }^{18}$

Dakwah merupakan aktivitas menyeru, mengajak, mempengaruhi manusia kepada kebaikan dengan hikmah dan pelajaran yang baik, agar objek dakwah (mad'u) beriman kepada Allah SWT, serta menjauhi larangan dan melaksanakan perintah Allah SWT, untuk mendapatkan kebahagiaan hidup di dunia dan akhirat. Aktivitas dakwah pada hakikatnya suatu proses mengadakan perubahan secara normatif sesuai dengan al-Qur'an dan sunnah Nabi Muhammad SAW. Tujuan dakwah adalah terwujudnya masyarakat yang mempercayai dan menjalankan sepenuhnya ajaran Islam. ${ }^{19}$

Berdakwah ada beberapa metode yang dapat diterapkan oleh seorang da'i agar tujuannya dapat tercapai, di antaranya: 1. Metode personal approach; Metode personal approach adalah suatu metode yang dilaksanakan dengan

\footnotetext{
18 Ibid., 197.

${ }^{19}$ Moh. Muafi bin Thohir, Metode Pembinaan Keagamaan yang efektif Bagi Narapidana/Tahanan Wanita di Lapas Kelas IIB Lumajang (Lumajang: LP3DI Press, 2012), 23.
} 
cara langsung melakukan pendekatan kepada setiap pribadi narapidana. 2. Metode ceramah dan diskusi; Metode ceramah merupakan suatu cara menyampaikan isi/bahan secara lisan oleh Pembina, sedangkan audien sebagai penerima pesan, memperhatikan, dan mencatat informasi. Metode diskusi yaitu Pembina memberikan kesempatan kepada Narapidana untuk meminta nasehat atau penerangan secara seorang demi seorang. 3. Metode Ta'widiyah (pembiasaan); Ilmu jiwa perkembangan mengenalkan teori konvergensi, dimana pribadi dapat dibentuk oleh lingkungannya, dengan mengembangkan potensi dasar yang ada padanya yaitu dengan cara melalui kebiasaan yang baik. Seperti Lapas Lumajang yang memberikan kegiatan yang baik, dan kebiasaan narapidana untuk mengikuti pembinaan yang telah disediakan. ${ }^{20}$

Dari beberapa metode tersebut, akan lebih baik jika diaplikasikan dalam beberapa pendekatan, di antaranya yaitu: a. Pendekatan personal, pendekatan antara da'i dan mad'u langsung bertatap muka sehingga materi yang disampaikan langsung diterima dan biasanya reaksi yang ditimbulkan oleh mad'u akan langsung diketahui. b. Pendekatan diskusi, pendekatan diskusi pada era sekarang sering dilakukan lewat berbagai diskusi keagamaan, da'i berperan sebagai narasumber sedang mad'u berperan sebagai audien. c. Pendekatan penawaran, cara ini dilakukan Nabi dengan memakai metode yang tepat tanpa paksaan sehingga mad'u ketika meresponnya tidak dalam keadaan tertekan bahkan ia melakukannya dengan niat yang timbul dari hati yang paling dalam. ${ }^{21}$

Kegiatan dakwah merupakan akumulasi dan upaya proses transformasi dan aktualisasi nilai-nilai keimanan yang dilakukan seorang muslim atau suatu lembaga keislaman dalam merealisasikan atau mewujudkan Islam sebagai ajaran, pandangan, dan kebutuhan hidup dalam kehidupan personal dan kolektif. Hal tersebut dilakukan melalui saluran dan media tertentu sesuai

\footnotetext{
${ }^{20}$ Ibid, Op., Cit, 37

${ }^{21}$ Abdul Wadud Nafis, Metode Dakwah Teori dan Praktek (Jakarta: Mitra Abadi Press, 2009), 84.
} 
dengan ragam dakwah yang terpilih, dengan mempertimbangkan situasi kondisi dan kebutuhan, dalam rangka menjawab tantangan dan peningkatan kualitas kehidupan dalam tolak ukur nilai-nilai Islami. ${ }^{22}$

Pola Komunikasi Dakwah; Pola komunikasi menunjukkan suatu identitas untuk mengakses tingkah laku komunikasi dalam suatu sistem, karena pola komunikasi menyediakan konteks atau ruang untuk memahami tingkah laku yang spesifik ${ }^{23}$. Pola komunikasi disesuaikan dengan kondisi anggota dan komunikan yang ada saat berinteraksi dengan lingkungannya. Pola ini bila dihubungkan dengan figur komunikator, pesan, dan media (tertulis, audio, dan video) akan menjadi suatu rangkaian yang beragam dan berkembang. Pola Komunikasi yang perlu dipahami oleh setiap komunikator agar pesan dakwah yang disampaikan dapat tercapai, terdapat empat pola komunikasi, di antaranya: a. Impromtu remaks (berbicara langsung apa yang difikirkan). B. Reding from manuscript (membaca naskah). C. Memorizing the speech (menghafal). D. Delivering extemporaneously (memaparkan dengan menggunakan catatan garis besarnya). ${ }^{24}$ Komunikasi dakwah umumnya akan menjadi optimal apabila dijalankan dengan memertimbakan aspek interaksi antara komunikator dan komunikan, serta pendekatan kultura. ${ }^{25}$

Memperbaiki diri Narapidana; Menjadi pribadi yang lebih baik adalah suatu proses memperbaiki diri. Untuk memperbaiki diri itu tidak mengenal kata terlambat dan batas usia, muda, remaja, dewasa, bahkan orang tua yang sudah memiliki umur saja masih bisa untuk memperbaiki diri agar menjadi pribadi yang lebih baik lagi. Begitu juga dengan narapidana, bahwa tidak ada

\footnotetext{
${ }^{22}$ Asep Muhyiddin dan Agus Ahmad Safei, Metode Pengembangan Dakwah ( Bandung: CV Pustaka Setia, 2002 ), 30.

${ }^{23}$ Eva Maghfiroh. (2016). Komunikasi Dakwah; Dakwah Interaktif Melalui Media Komunikasi. Dakwatuna: Jurnal Dakwah dan Komunikasi Islam, 2(1), 34-48.

24 Bambang Saiful Ma'arif, Komunikasi Dakwah Paradigma Untuk Aksi (Bandung: Simbiosa Rekatama Media, 2010), 79.

${ }^{25}$ Rio Febriannur Rachman. (2018). Dakwah Intraktif Kultural Emha Ainun Nadjib. Jurnal Spektrum Komunikasi, 6(2), 1-9.
} 
kata terlambat untuk memperbaiki diri, selama nyawa masih menetap dalam jasad. Berada di Lapas bagi para narapidana harus disyukuri dan dimanfaatkan sebaik mungkin untuk bertaubat dan memperbaiki diri, sebab Lapas dapat menjadi gerbang awal untuk menjadi insan yang lebih baik.

Keberhasilan Dakwah; Dakwah sangat berperan penting dalam kehidupan manusia, untuk itu seorang da'i harus mampu meyakinkan orang lain (mad'u) tentang ajaran Islam. Dalam hal ini dakwah memiliki indikator keberhasilannya setelah penyampaian pesan-pesan yang dilakukan kepada mad'u, di antara indikator keberhasilan dakwah yaitu : a. Terbentuknya suatu pengertian atau pengetahuan (knowledge), b. Proses suatu sikap menyetujui atau tidak menyetujui (attitude), c. Proses terbentuknya gerak pelaksanaan (prectice). Dari ketiga indikator tersebut, terdapat 3 efek perubahan perilaku pada seseorang, di antaranya yaitu : a. Efek kognitif, yaitu setelah menerima pesan dakwah, mad'u akan menyerap isi dakwah tersebut melalui proses berfikir. Jadi, dengan menerima pesan dakwah, diharapkan mad'u dapat merubah cara berfikirnya tentang ajaran agama sesuai dengan pemahaman yang sebenarnya. b. Efek afektif, yaitu perubahan sikap mad'u setelah menerima pesan dakwah. Sikap adalah sama dengan proses belajar dengan tiga variabel sebagai penunjangnya, di antaranya perhatian, pengertian, dan penerimaan. c. Efek behavioral, yaitu suatu bentuk pola tingkah laku mad'u dalam merealisasikan pesan dakwah yang telah diterima dalam kehidupan sehari-hari. Maka dakwah dapat dikatakan berhasil dengan baik, dan inilah tujuan final dakwah. Dakwah sendiri harus bisa mengikuti perkembangan zaman agar tujuan final tersebut bisa tercapai ${ }^{26}$.

Dari semua perubahan perilaku manusia setelah menerima pesanpesan dakwah, menurut Majdi Hilali bahwa setiap perubahan perilaku mengalami tiga tahap yaitu akal berupa keyakinan tentang suatu tindakan,

\footnotetext{
${ }^{26}$ Abdul Ghofur. (2019). Dakwah Islam Di Era Milenial. Dakwatuna: Jurnal Dakwah dan Komunikasi Islam, 5(2), 136-149.
} 
hati berupa suara bisikan yang menyenangkan dan hawa nafsu yang diwujudkan oleh anggota tubuh dalam bentuk tidak nyata. ${ }^{27}$

Faktor Pendukung dan Penghambat menurut Analisis SWOT; Analisis SWOT adalah suatu metode perencanaan strategis yang digunakan untuk mengevaluasi faktor-faktor yang menjadi kekuatan (Strengths) yaitu situasi atau kondisi yang merupakan kekuatan dari lembaga atau program saat itu. Kelemahan (weaknesses) yaitu situasi atau kondisi yang merupakan kelemahan dari lembaga atau program saat itu. Peluang (opportunities) yaitu situasi atau kondisi yang merupakan peluang dari lembaga atau program saat itu. Ancaman threats) yaitu situasi atau kondisi yang merupakan ancaman dari lembaga atau program saat itu yang mungkin terjadi dalam mencapai suatu tujuan dari kegiatan usaha dalam skala yang lebih luas. Untuk mencari faktor pendukung dan faktor penghambat dalam implementasi komunikasi organisasi dalam kegiatan dakwah untuk meemperbaiki diri narapidana di Lapas Klas IIB Lumajang, maka sangat perlu menerapkan analis SWOT. ${ }^{28}$

\section{KESIMPULAN}

Da’i yang mengisi kegiatan dakwah di Lingkungan Narapidana Lapas juga mempunyai program dakwah dari warga binaan itu sendiri. Program dakwah tersebut dilakukan setelah shalat ashar, yang memberi ceramah warga binaan sendiri yang mempunyai kemampuan dan keberanian untuk menyampaikan hal-hal yang dipahami dan diketahui mengenai ajaran agama Islam. Durasi menyampaikan memang tidak lama-lama hanya sekitar 30-45 menit saja, pedoman yang menjadi dasar berdakwahnya da'i biasanya menggunakan kitab atau langsung dengan ilmu yang mereka miliki, hal itu tidak terikat dengan kitab, tetapi bisa juga diakses dari artikel.

\footnotetext{
${ }^{27}$ Moh. Ali Aziz, Ilmu Dakwah (Jakarta: Kencana Prenada Media Group, 2004), 454-460.

${ }^{28}$ Khairuddarni, Manajemen Dakwah Islam, ( Jakarta: PT Pustaka Firdaus, 1989 ), 65
} 
Materi yang menjadi pedoman dalam kegiatan dakwah di lingkungan narapidan Lapasbersumber dari al-Quran dan Hadist. Penentuan materi yang disampaikan oleh para da'i telah diatur oleh takmir masjid, materi ditentukan oleh takmir masjid agar para da'i dalam menyampaikan dakwahnya tidak ada yang membawakan materi yang sama. Adapun materi yang dibawakan para da'i berupa muhasabah yang bertujuan untuk membuat narapidana samakin mendekatkan diri kepada Alla swt, penyampaian hakikat manusia kepada para narapidana agar mereka dapat menyadari kesalahan yang mereka lakukan, menyampaikan ilmu agama yang dimiliki para da’i.

Metode yang diberikan ustadz maupun takmir Lapas lebih kepada nasihat perilaku dan ibadah. Secara umum kejadian yang telah terjadi kepada warga binaan Lapas merupakan ketentuan yang telah ditetapkan Allah SWT diibaratkan oleh ustadz tersebut daun yang kering pun tidak akan jatuh jika tidak dengan izin sang pencipta, begitu juga dengan garis kehidupan yang diberikan Allah SWT kepada warga binaan . Media dalam berdakwah meliputi sarana dan prasarana. Kegiatan dakwah yang dilakukan di Lapasmeliputi ruang masjid yang memadai dengan keadaan narapidana yang ada di lingkungan Lapas. Lokasi masjid yang dapat menampung lebih kurang 300 orang menjadi sarana yang baik pada kegiatan dakwah yang dilakukan.

Diantara Faktor Pendukungnya; Kerja pegawai dan staf yang sangat baik dan bertanggung jawab kepada tugas masing-masing, Kerja sama yang baik dengan berbagai lembaga demi mendukung kelancaran pembinaan dan keamanan Lapas Klas IIB Lumajang, Banyaknya kegiatan pembinaan yang bermacam-macam, mulai dari pembinaan agama, kerja, dan hiburan, Pelayanan yang baik dari pegawai dan petugas kepada warga binaan dan pengunjung, Kegiatan dakwah yang terjadwal dengan baik dan Pemateri dakwah/pembimbing yang merupakan orang-orang ahli dibidangnya.

Adapun Faktor Penghambat; Kurangnya pegawai atau tenaga kerja, Keterbatasan media dakwah, Keterbatasan tempat yang terlalu sempit dan 
masjid yang tidak masuk dalam area steril, Banyaknya narapidana di lapas Lumajang hingga melebihi kapasitas, serta banyaknya pemindahan dari lapas lain, Pemateri yang kadang tidak bisa hadir karena terkendala sesuatu, Terjadinya benturan dengan kegiatan lain dan Adanya narapidana residivis.

Hasil kegiatan dakwah yang dilakukan di lingkungan narapidana menjadikan para narapidana lebih mendekatkan diri pada Allah.dan mampu mengimplementasikannya dalam kehidupan sehari.

Adapun saran diharapkan kepada Lapas untuk terus meningkatkan sistem dakwah dan kebutuhan warga binaan dalam melakukan aktivitas dakwah agar selalu mengamalkannya. Diharapkan kepada takmir agar bisa terus mengembangkan sistem dakwah di Lapas guna memperbaiki akhlak dan amal para warga binaan supaya menjadi orang yang berguna di kalangan masyarakat nantinya. Diharapkan kepada warga binaan agar tetap lebih sabar dan selalu mengamalkan apa-apa yang telah di ajarkan atau diterangkan oleh ustadz.

\section{REFERENSI}

A. Royad Shaleh, 2010. Manajemen Dakwah Islam, Jakarta: Al-Ikhlas. Al-Quran, Kementrian Agama RI. 2010. Az-Zikru. Jakarta: Wali. Aziz, Moh. Ali. 2009. Ilmu Dakwah. Jakarta: Prenada Media Group.

Ghofur, A. (2019). Dakwah Islam Di Era Milenial. Dakwatuna: Jurnal Dakwah dan Komunikasi Islam, 5(2), 136-149.

Guntur Setiawan, Impelemtasi dalam Birokrasi Pembangunan, Jakarta: Balai Pustaka, 2004

Hadi, Nur dan amar Ma'ruf. 2013. Mengkaji Tafsir. Solo: Aqila.

Kasiram, Moh. 2010. Metode Penelitian Kualitatif Kuantitatif. Yogyakarta: UIN Maliki Press.

Maghfiroh, E. (2016). Komunikasi Dakwah; Dakwah Interaktif Melalui Media 
Komunikasi. Dakwatuna: Jurnal Dakwah dan Komunikasi Islam, 2(1), 34-48.

Muhammad, Arni. 2008. Komunikasi Organisasi. Jakarta: Bumi Aksara. Muhyidin, Asep dan Agus Ahmad Safei. 2002. Metode Pengembangan Dakwah:

Mulyana, Deddy. 2007. Ilmu Komuikasi Suatu Pengantar. Bandung: PT Remaja Rosdakarya.

Nafis, Abdul Wadud. 2009. Metode Dakwah Teori dan Praktek.Jakarta: Mitra Abadi Press.

Nurdin Usman, Konteks Implementasi Berbasis Kurikulum, Jakarta: Grasindo, 2002

Pace, R. Wayne dan Don F. Faules. 2001. Komunikasi Organisasi Strategi Meningkatkan Kinerja Perusahaan. Bandung: PT Remaja Rosdakarya.

Rachman, R. F. (2018). Dakwah Intraktif Kultural Emha Ainun Nadjib. Jurnal Spektrum Komunikasi, 6(2), 1-9.

Rachman, R. F. (2019). Optimalisasi Media Digital Berbasis Kemaslahatan Umat dalam Program Pahlawan Ekonomi Surabaya. IQTISHODUNA: Jurnal Ekonomi Islam, 8, 273-292.

Rachman, R. F. (2019). Optimalisasi Teknologi Komunikasi Informasi Command Center Bagi Efektifitas Tenaga Kesejahteraan Sosial Kecamatan. Dakwatuna: Jurnal Dakwah dan Komunikasi Islam, 5(2), 170-180.

Rachman, R. F. (2019). Pengembangan Industri Kreatif Berbasis Media Digital di Surabaya dalam Perspektif Islam. KOMUNITAS, 10(2), 157-176.

Rachman, R. F. (2020). Kebijakan Pendidikan Anak Berkebutuhan Khusus Di Surabaya Dalam Perspektif Islam. Bidayatuna: Jurnal Pendidikan Guru Mandrasah Ibtidaiyah, 3(01), 125-143.

Romli, Khomsahrial. 2014. Komunikasi Organisasi Lengkap. Jakarta: PT Grasindo. 
Implementasi Komunikasi Organisasi dalam Kegiatan Dakwah

Thohir, Moh. Muafi. 2012. Metode Pembinaan Keagamaan yang Efektif bagi narapidana dan Tahanan Wanita di Lapas Kelas IIB Lumajang. Lumajang: LP3DI. 